\title{
MENUMBUHKAN INTENSI BERWIRAUSAHA PADA MAHASISWA MANAJEMEN UNIVERSITAS PAMULANG
}

\author{
Krida Puji Rahayu*) \\ dosen01666@unpam.ac.id
}

\begin{abstract}
ABSTRAK
Penelitian ini bertujuan untuk mengetahui karakteristik kewirausahaan mahasiswa Universitas Pamulang (UNPAM) dan faktor-faktor yang mempengaruhi intensi kewirausahaan mahasiswa UNPAM. Intensi berwirausaha adalah kepedulian atau ketertarikan seseorang terhadap hal-hal kewirausahaan. Dengan adanya pendidikan kewirausahaan diharapkan mahasiswa memiliki jiwa wirausaha serta wadah bagi mahasiswa untuk berwirausaha. Pendidikan kewirausahaan digunakan untuk menumbuhkan jiwa wirausaha dan memberikan bekal pengetahuan kepada mahasiswa supaya dapat menciptakan lapangan pekerjaan setelah lulus nanti.
\end{abstract}

\section{Kata Kunci : menumbuhkan minat, Intensi Berwirausaha.}

\begin{abstract}
This study aims to determine the entrepreneurial characteristics of students Pamulang University (UNPAM) and the factors that affect the intention of entrepreneurship UNPAM students. The intention of entrepreneurship is the concern or interest of a person to the things of entrepreneurship. With the entrepreneurship education students are expected to have an entrepreneurial spirit as well as a forum for students to entrepreneurship. Entrepreneurship education is used to foster entrepreneurial spirit and provide knowledge to students so that they can create jobs after graduation.
\end{abstract}

Keywords: cultivate interest, Intensi Entrepreneurship

\section{A. Pendahuluan}

Persaingan dalam seleksi pekerjaan yang ketat menjadikan cendekiawan muda mendapatkan pekerjaan yang kurang layak atau bahkan menjadi pengangguran. Hal ini mengakibatkan jumlah pengangguran

di Indonesia meningkat. Tingkat pengangguran tinggi akan menimbulkan masalah sosial yang cukup tinggi pula apabila tidak memperoleh perhatian serius. Beberapa masalah sosial yang dipengaruhi oleh tingginya pengangguran diantaranya kemiskinan, penyalahgunaan narkoba, kriminalitas, pergaulan bebas, premanisme, jual beli manusia (human trafficking), dan lain sebagainya. Kondisi tersebut akan menganggu pembangunan di segala bidang dan stabilitas nasional. 
Badan pusat statistik (BPS) mencatat jumlah pengangguran sarjana atau lulusan universitas pada Februari 2013 mencapai 260 ribu orang atau 5,04\% dari total pengangguran yang mencapai 7,2 juta orang (Santosa, 2013). Berdasarkan pada data tersebut, perguruan tinggi perlu melakukan pembenahan supaya pembelajaran selama perkuliahan mampu mengubah orientasi mahasiswa dari pencari kerja menjadi penyedia lapangan kerja.

Pihak instansi pemerintah dan swasta sudah tidak bisa menjamin ketersediaan lapangan pekerjaan, dikarenakan tingkat persaingan dalam melamar pekerjaan semakin tinggi. Oleh karena itu, perguruan tinggi diharapkan melakukan upaya pembenahan selama pembelajaran di perkuliahan, supaya dapat mengubah karakter mahasiswa dari pencari kerja menjadi pencipta lapangan kerja atau berwirausaha.

Kewirausahaan diartikan sebagai suatu usaha yang dapat melihat kesempatan bisnis dan manajemen pengambilan risiko dari peluang yang ada kemudian mampu menggerakkan manusia dan sumberdaya untuk menghasilkan produk tertentu (Ranto, 2007).

Kewirausahaan menurut Sukidjo (2011) mencerminkan semangat, sikap, dan perilaku sebagai teladan dalam keberanian mengambil resiko yang telah diperhitungkan berdasar atas kemauan dan kemampuan sendiri. Orang yang memiliki sikap-sikap tersebut dikatakan sebagai wiraswasta atau wirausaha.

Salah satu faktor pendorong pertumbuhan kewirausahaan di suatu negara terletak pada peranan perguruan tinggi melalui penyelenggaraan pendidikan kewirausahaan (Suharti \& Sirine, 2011:125). Pihak perguruan tinggi bertanggung jawab dalam mendidik mahasiswanya serta memberikan motivasi sehingga mereka berani untuk berwirausaha. Perguruan tinggi sebagai penyedia fasilitas kewirausahaan, tidak akan mencapai tujuannya dalam menghasilkan lulusan yang berwirausaha bila tidak disertai dengan minat yang timbul dalam diri mahasiswa. Dengan demikian, persoalan yang dihadapi perguruan tinggi adalah bagaimana cara menumbuhkan minat berwirausaha pada mahasiswa sehingga pilihan karir yang mereka pilih setelah lulus adalah sebagai wirausahawan.

Indarti dan Rostiani, (2008) berpendapat bahwa pengaruh pendidikan kewirausahaan selama ini telah dipertimbangkan sebagai salah satu faktor penting untuk menumbuhkan dan mengembangkan hasrat, jiwa dan perilaku berwirausaha di kalangan generasi muda. Terkait dengan pengaruh pendidikan kewirausahaan tersebut diperlukan adanya pemahaman tentang bagaimana mengembangkan dan 
mendorong lahirnya wirausaha-wirausaha muda yang potensial dan dalam penelitian sebelumnya (Indarti dan Rostiani, 2008) juga menyebutkan bahwa keinginan berwirausaha para mahasiswa merupakan sumber bagi lahirnya wirausaha-wirausaha masa depan.

Lebih lanjut Indarti dan Rostiani, (2008) menjelaskan bahwa Sikap, perilaku dan pengetahuan mereka tentang kewirausahaan akan membentuk kecenderungan mereka untuk membuka usaha-usaha baru di masa mendatang.

Berdasarkan penelitian yang dilakukan oleh Li Wei, (2006) menemukan bahwa pendidikan kewirausahaan mempengaruhi minat para kaum muda untuk menjadi seorang pengusaha dan dibutuhkan pemahaman mengenai minat wirausaha dalam rangka untuk memelihara potensi usahawan selama mereka belajar di universitas.

Hasil dari penelitian yang dilakukan Li Wei, (2006) memperlihatkan bahwa mahasiswa lebih tertarik dengan bisnis mereka sendiri, dan menunjukan lebih dari dua-per tiga (68.4\%) siswa yang diwawancarai ingin memiliki bisnis sendiri.

Scherer et al., (dalam Linan and Chen, 2006) menjelaskan bahwa secara umum pendidikan juga akan meningkatkan kepedulian seseorang tentang adanya pilihan karir wirasusahawan. Variabel pendidikan juga mempengaruhi kepercayaan seseorang tentang kemampuannya (self-efficiacy) dan social norms. Sehingga diharapkan pengetahuan kewirausahaan dapat mempunyai pengaruh positif terhadap intensi berwirausaha.

Menurut Wijaya (2007), intensi merupakan suatu kebulatan tekad untuk melakukan aktifitas tertentu atau menghasilkan suatu keadaan tertentu di masa depan. Maka intensi kewirausahaan dapat diartikan sebagai niat yang ada pada diri seseorang untuk melakukan tindakan wirausaha kemudian mengembangkan usaha tersebut.

Basu dan Virick (2007) mengadakan penelitian tentang intensi berwirausaha. Penelitian tersebut menguji variabel pendidikan, orangtua yang sudah memiliki bisnis, pengalaman bekerja yang diduga dipengaruhi oleh tiga determinan yang mempengaruhi intensi berwirausaha. Penelitian tersebut menunjukkan bahwa variabel pendidikan, keluarga memiliki hubungan positif terhadap attitudes toward entrepreneurship, subjective norms, dan perceived behavioural control mempengaruhi minat kewirausahaan mahasiswa.

Bygrave (2003), menyatakan minat wirausaha belum tumbuh ketika kita lahir tetapi tumbuh dan berkembang sesuai dengan faktor-faktor yang 
mempengaruhinya. Faktor yang mempengaruhi tumbuhnya minat untuk berwirausaha meliputi karakter kepribadian seseorang dan lingkungannya. Indarti dan Rostiani (2008), menyatakan bahwa terdapat perbedaan faktor yang mempengaruhi intensi kewirausahaan antara satu negara dengan negara lain. Faktor efikasi diri berpengaruh terhadap intensi mahasiswa Indonesia dan Norwegia. Faktor lain yang mempengaruhi intensi wirausaha yaitu latar belakang pendidikan, kebutuhan akan prestasi, umur dan gender.

Berdasarkan beberapa pendapat diatas dapat disimpulkan bahwa minat merupakan suatu kecenderungan, ketertarikan atau rasa suka yang lebih besar terhadap suatu hal kemudian dipelajari dan terus dikembangkan secara mendalam hingga tujuan yang diinginkannya tercapai. Sehingga minat dalam diri pribadi yang semakin kuat dapat menumbuhkan intensi seseorang untuk berwirausaha.

\section{B. Rumusan Masalah}

Bagaimana karakteristik kewirausahaan mahasiswa Unniversitas Pamulang dan faktor faktor apa saja yang mempengaruhi intensi kewirausahaan mahasiswa Unniversitas Pamulang?

\section{Tujuan Penelitian}

Untuk mengetahui karakteristik kewirausahaan mahasiswa Unniversitas Pamulang dan faktor faktor apa saja yang mempengaruhi intensi kewirausahaan mahasiswa Unniversitas Pamulang?

\section{Metode Penelitian}

Lokasi penelitian ini dilakukan di Universitas Pamulang (UNPAM). Responden ditentukan dengan metode accidental sampling sebesar 10 persen dari populasi yang ada. Populasi dipilih dari seluruh mahasiswa Fakultas Ekonomi, Program Studi S1-Manajemen untuk memberikan gambaran wirausaha agar mahasiswa memiliki jiwa wirausaha.

Pengumpulan data dilakukan dengan cara wawancara dan pengamatan. Wawancara dilakukan dengan cara wawancara mendalam (indepth interview) dan wawancara terstruktur (structured interview) dengan menggunakan kueisioner.

Metode pengumpulan data menggunakan kuesioner yang diisi oleh responden dibuat dalam bentuk pertanyaan terbuka. Untuk masing-masing karakteristik 
sebanyak dua belas pertanyaan, dengan alasan dua belas. Pertanyaan ini dianggap cukup mewakili dari sub-sub karakteristik yang diinginkan.

Alternatif jawaban disesuaikan dengan skala likert yang dibuat menjadi empat alternatif jawaban (Sugiyono, 2006). Skala likert melibatkan serangkaian pernyataan yang berkaitan dengan sikap. Sikap yang diteliti dalam penelitian ini berupa: pendapat yang terdiri dari sangat setuju, setuju, tidak setuju dan sangat tidak setuju. Tangggapan diberi nilai secara konsisten terhadap sikap responden. Nilai total seluruh pernyataan dihitung untuk setiap responden.

\section{Analisis Data}

Pada penelitian ini, analisis data dilakukan secara deskriptif kuantitatif. Analisis deskripsi mengenai tanggapan yang diberikan responden pada kuesioner. Analisis deskriptif dilakukan terhadap kebutuhan akan prestasi, efikasi diri, akses terhadap modal, akses terhadap informasi, akses terhadap jaringan sosial, latar belakang pendidikan, jenis kelamin dan latar belakang keluarga.

\section{Analisis Deskriptif}

Analisis deskriptif merupakan metode yang digunakan untuk menjawab permasalahan pertama yang ada pada tujuan penelitian yaitu untuk mengetahui bagaimana karakteristik kewirausahaan mahasiswa Universitas Pamulang yang terdiri atas variabel efikasi diri, latar belakang keluarga, latar belakang pendidikan, akses terhadap informasi, kebutuhan akan prestasi dan jenis kelamin. Metode analisis deskriptif kualitatif yaitu memberikan ulasan mengenai fakta, keadaan dan fenomena yang terjadi ketika penelitian berlangsung dan menyajikan apa adanya.

\section{Analisis Diskriminan}

Analisis diskriminan merupakan metode analisis data yang digunakan untuk mengelompokkan individu berdasarkan lebih dari satu variabel bebas, dimana variabel dependen merupakan data kategorik atau kualitatif, sedangkan variabel independen berupa data kuantitatif (interval atau rasio).

Asumsi dalam analisis diskriminan:

a. Sejumlah variabel independen harus berdistribusi normal

b. Tidak ada korelasi antar variabel independen

c. Tidak terdapat data yang outlier pada variabel independen. 


\section{Uji Hipotesis :}

$\mathrm{HO}$ : ada perbedaan signifikan antara mahasiswa yang bercita-cita menjadi wirausaha

H1 : tidak terdapat perbedaan antara mahasiswa yang tidak bercita-cita menjadi wirausaha.

Untuk menguji kesamaan rata-rata variabel dengan melihat tabel Test of Equality of Group Means. Keputusan hipotesis dengan melihat nilai signifikansi:

a. Jika nilai sig $>0,05$ maka tidak ada perbedaan dalam kelompok

b. Jika nilai sig < 0,05 maka terdapat perbedaan dalam kelompok.

Untuk menguji kesamaan varian digunakan angka Box $\mathrm{M}$ dengan ketentuan sebagai berikut :

a. Jika nilai sig $>0,05$ maka $\mathrm{HO}$ diterima

b. Jika nilai sig $<0.05$ maka $\mathrm{H} 1$ diterima

\section{Hipotesis :}

a. HO : varians kedua kelompok data identik / homogeny

b. H1 : varians kedua kelompok data tidak sama / heterogen.

Model persamaan analisis diskriminan sebagai berikut :

$Y=\beta 0+b 1 X 1+b 2 X 2+b 3 X 3+b 4 X 4+b 5 X 5+\ldots . . b n X n+\varepsilon$

Dimana $\mathrm{Y}$ adalah Intensi Kewirausahaan Skor $1=$ responden memiliki cita-cita ingin menjadi pengusaha, Skor $0=$ responden tidak memiliki cita-cita menjadi pengusaha, X1 adalah efikasi diri, X2 adalah latar belakang orang tua, X3 adalah latar belakang pendidikan, X4 adalah akses terhadap informasi, X5 adalah kebutuhan akan prestasi, X6 adalah Gender, $\boldsymbol{\beta} \mathbf{0}$ adalah konstanta, b1, b2 adalah koefisien regresi, dan $\boldsymbol{e}$ adalah error term.

\section{E. Hasil Dan Pembahasan}

\section{Uji Validitas}

Hasil pengujian validitas pada masing-masing variabel penelitian, menunjukkan bahwa semua item pertanyaan pada variabel penelitian variable $\mathbf{X} 1$ adalah efikasi diri, X2 adalah latar belakang orang tua, X3 adalah latar belakang 
pendidikan, X4 adalah akses terhadap informasi, X5 adalah kebutuhan akan prestasi, X6 adalah Gender, mempunyai nilai $r$ hitung $>0,440$ dengan demikian dua belas item pertanyaan pada tiap variabel di atas adalah valid, hal ini berarti dua belas item pada tiap variabel mampu mengukur secara tepat variabel-variabel yang diteliti.

\section{Uji Realibilitas}

Hasil pengujian reliabilitas pada masing-masing variabel penelitian. Diketahui bahwa besarnya Cronbach Alpha pada kedelapan variabel lebih besar dari $r$ tabel 0,323 yaitu $(0,900>0,323)$, hal ini berarti kedelapan variabel penelitian dinyatakan reliabel.

\section{Analisis Deskriptif}

Hasil analisis deskriptif dari sampel sebanyak 200 responden disebarkan ke mahasiswa Manajemen. Peneliti memberikan 4 alternatif jawaban kepada responden dengan menggunakan skala likert yaitu sangat setuju, setuju, tidak setuju dan sangat tidak setuju. Terdapat 5 karakteristik responden diantaranya: usia, jenis kelamin, cita-cita, pekerjaan orang tua, keinginan orang tua.

Karakteristik berdasarkan usia responden menunjukkan bahwa usia terbanyak yang mengisi kuesioner yaitu usia 18 sebesar 19\%, usia 19 sebesar 25\%, usia 20 sebesar 26\%, usia 21 sebesar 13\% dan usia 22 sebesar 17\%. Sedangkan karakteristik responden berdasarkan jenis kelamin, dari 200 kuesioner responden terbanyak dari jenis kelamin perempuan sebesar $64 \%$ sedangkan laki-laki sebesar $36 \%$.

Berdasarkan hasil kuesioner, tanggapan berwirausaha bahwa laki-laki lebih tinggi memiliki tingkat percaya diri daripada perempuan. Hasil menunjukkan bahwa sebagian besar jawaban laki-laki sebesar $62 \%$ kurang menyetujui bahwa percaya diri perempuan lebih rendah dibandingkan dengan laki- laki untuk memulai usaha.

Sedangkan berdasarkan cita-cita responden menunjukkan bahwa cita-cita mahasiswa UNPAM bercita-cita ingin menjadi PNS dikarenakan ingin mengikuti jejak orang tua mereka. Selain itu, sebagian besar mahasiswa memiliki keyakinan bahwa menjadi PNS lebih menjamin karena mendapatkan uang pensiun meskipun pesaingnya banyak.

Karaktersitik berdasarkan pekerjaan orang tua dari responden menunjukkan bahwa pekerjaan orang tua merupakan faktor pembentuk wirausaha mahasiswa. Kebanyakan orang tua menginginkan anaknya lebih sukses dari orang tuanya, Vol. 1 No.3 / April 2018 
seorang anak juga akan cenderung mengikuti jejak orang tuanya atau melanjutkan pekerjaan orang tuanya.

Sebagian besar orang tua menginginkan anaknya untuk menjadi PNS, pengusaha, dosen dan jurnalis. Hal ini ditunjukkan bahwa mayoritas orang tua mahasiswa berkeinginan supaya anaknya menjadi PNS. Keterangan tersebut sebanding dengan cita-cita mahasiswa, pekerjaan orang tua mahasiswa dan keinginan orang tua mahasiswa UNPAM. Mayoritas orang tua menginginkan anaknya menjadi pegawai daripada menjadi wirausahawan, dosen dan sebagainya.

\section{Analisis Diskriminan}

Analisis diskriminan bertujuan untuk mengelompokkan suatu pengamatan ke dalam kategori yang saling bebas dan menyeluruh berdasarkan sejumlah variabel penjelas.

Berdasarkan faktor-faktor yang mempengaruhi intensi kewirausahaan mahasiswa Universitas Pamulang yaitu faktor kepribadian meliputi: kebutuhan akan prestasi, efikasi diri, dan akses terhadap informasi serta faktor demografi yang meliputi: latar belakang pendidikan, gender dan latar belakng orang tua.

Dari 6 variabel di atas dapat dilihat bahwa faktor kepribadian yakni efikasi diri, faktor lingkungan yaitu akses terhadap modal dan factor demografi yakni meliputi latar belakang pendidikan dan latar belakang orang tua yang memiliki pengaruh signifikan terhadap intensi kewirausahaan mahasiswa di Universitas Pamulang. Hal ini menyatakan bahwa mayoritas mahasiswa Universitas Pamulang memiliki intensi kewirausahaan rendah, karena mahasiswa takut mengambil risiko dalam menjalankan usaha, tidak memiliki modal dalam memulai usaha dan latar belakang pendidikan memiliki pengaruh dalam menentukan sukses tidaknya usaha serta latar belakang orang tua menginginkan anaknya untuk menjadi pegawai. Padahal mahasiswa Universitas Pamulang diharapkan mampu menciptakan lapangan pekerjaan setelah mereka lulus nanti,. Pemberian mata kuliah kewirausahaan dan program DIKTI diharapkan mampu berjalan dengan baik agar mampu mengubah mindset mahasiswa dari pencari lapangan pekerjaan menjadi pencipta lapangan kerja.

Hasil penelitian di atas didukung oleh penelitian Koesworo, dkk (2006) menyatakan bahwa variabel efikasi diri dan toleransi akan risiko terbukti secara 
parsial dan simultan mempengaruhi niat mahasiswa berwirausaha. Jumiadi (2004) menunjukkan bahwa modal dan tenaga kerja memiliki pengaruh positif terhadap pendapatan dan perkembangan industri kecil dibandingkan dengan teknologi.

Selain itu, Setiyorini (2009) menunjukkan bahwa efikasi diri, akses terhadap informasi motivasi berprestasi dan akses terhadap modal berpengaruh sebesar 44\% terhadap minat wirausaha mahasiswa Universitas Sebelas Maret Surakarta dan sisanya 56\% dijelaskan oleh faktor lain. Farzier dan Niehn (2008) menyatakan bahwa pendidikan dan pelatihan memiliki pengaruh terhadap persepsi orang dalam berwirausaha, artinya pendidikan kewirausahaan tidak hanya dilakukan dalam perkuliahan saja melainkan mahasiswa diberikan kesempatan untuk terjun langsung misal dalam bentuk magang kewirausahaan.

Penelitian oleh Isdianto dkk, (2005) menyatakan peran keluarga memiliki pengaruh positif dalam mendorong minat anak dalam berwirausaha. Hasil penelitian Morello, dkk (2003) di Ekuador berjumlah sebanyak 852 mahasiswa, $61,4 \%$ diantaranya responden laki-laki dan sisanya $38,6 \%$ adalah wanita, menyatakan bahwa mahasiswa yang memiliki orang tua sebagai pengusaha maka memiliki intensi kewirausahaan yang tinggi jika dibandingkan dengan mahasiswa yang orang tuanya berprofesi selain wirausaha.

Sedangkan menurut Galloway, dkk (2006) menyatakan bahwa orang tua yang berprofesi sebagai wirausaha berpengaruh terhadap minat anak untuk menjadi wirausaha di masa depan. Sedangkan penelitian menurut Mazzarol, dkk (2006) bertolak belakang dengan penelitian di atas yang menyatakan bahwa variabel gender, usia, pendidikan dan pengalaman bekerja mempengaruhi seseorang untuk menjadi penelitian Segal, dkk (2005) dan Wijaya (2008), yang menunjukkan hasil efikasi diri tidak mempengaruhi intensi kewirausahaan.

\section{F. Kesimpulan}

Karakteristik kewirausahaan mahasiswa berdasarkan kendala usaha dipengaruhi 3 faktor yakni diantaranya: tidak memiliki pengalaman, modal dan tidak berani mengambil risiko. Karakter mahasiswa berdasarkan cita-cita ingin menjadi PNS sebesar $30 \%$ dan mayoritas keinginan orang tua mahasiswa ingin anaknya menjadi pegawai sebesar $79 \%$ dan pengusaha sebesar $21 \%$. Dari 6 variabel yang mempengaruhi intensi kewirausahaan hanya terdapat 4 variabel yang berpengaruh, diantaranya: efikasi diri, akses terhadap modal, latar belakang 
pendidikan dan latar belakang orang tua. Peran orang tua berpengaruh terhadap pembentukan sikap dan karakter mahasiswa dalam menentukan bidang pekerjaan setelah wisuda.

\section{G. Daftar Pustaka}

Basu, A., and Meghna Virick. 2007. Assesing Entrepreneurial Intentios Among Students: A Comparative Study. Peer-Reviewed Papers, 71-86.

Bygrave, W. D. 2003. The Portable MBA Entrepreneurship. Binarupa Aksara. Jakarta.

Farzier, Barbara dan Niehm, Linda S. 2008. "Students attitudes and intentions toward entrepreneurial careers", Journal of family and consumer sciences 7(2): 281-294.

Galloway, L., Anderson, M. and Brown, W. 2006. "Are engineers becoming more enterprising? A study of the potentials of entrepreneurship education", International Journal of Continuing Engineering Education and Lifelong Learning 16(5): 355-365.

Indarti, N. dan Rostiani, N. 2008. Intensi Kewirausahaan Mahasiswa: Studi Perbandingan Antara Indonesia, Jepang dan Norwegia. Jurnal Ekonomika dan Bisnis Indonesia 23(4): 371-383.

Isdianto, B., Willy, D. \&Mashudi, M.R. 2005. Orientasi Sistem Pendidikan Desain Interior terhadap Motivasi Kewirausahaan Mahasiswa (Mencari Hambatan dan Stimulus). Laporan Penelitian Bandung: Institut Teknologi Bandung.

Jumiadi, W. 2004. Analisis Pengaruh Perkembangan Industri Kecil Pakaian Jadi Terhadap Pengembangan Wilayah Kota Medan. Tesis. Magister Perencanaan Wilayah. USU. Medan.

Koesworo, Y., Sina. S. S., Nugeraheni, D. B. 2006. "Motivasi berwirausaha di kalangan mahasiswa: aplikasi theory of planned behavior". Jurnal Ekuitas 11(2): 269-291.

Li, Wei. 2006. Entrepreneurial Inention Among Intrenational Students:Testing a model of entrepreneurial inention. Journal University of Illinois at UrbanaChampaign, 217-721-9969.

Linan, Francisco and Yi-Wen Chen. 2009. Development and Cross Cultural Appliation Of a Specific Instrument To Measure Entrpreneurial Intentions.

Mazzarol T., T. Volery, N. Doss, dan V. Thein. 2006. Factor enhancing the effect of word-of-mouth onconsumer outcomes. Conference Paper.

Morello, Virginia Lasio, Dirk Deschoolmeester dan Elizabeth Arteaga Garcia. 2003. "Entrepreneurial Intention of Undergraduates at ESPOL in Equador.

Ranto, Basuki. 2007. Analisis Hubungan Antara Motivasi, pengetahuan kewirausahaan, dan kemandirian usaha terhadap kinerja pengusaha pada kawasan industri kecil di daerah pulogadung. Jurnal Usahawan (10).

Santosa, A. 2013. "Tahun 2013, 300 ribu sarjana di Indonesia masih menganggur".http://copasloker.blogspot.com/2013/05/ tahun-2013-300ribusarjana-di.html. diakses pada 24 Oktober 2017. 
Segal, Gary, Dan Borgia, and Jerry Schoenfeld. 2005. The motivation to become an entrepreneur. International Journal of Entrepreneurial Behaviour and Research.

Setiyorini, Mamik. 2009. Pengaruh faktor kepribadian dan lingkungan terhadap keinginan berwirausaha. Universitas Sebelas Maret Surakarta.

Sugiyono. 2006. Teknik Penelitian. Pines. Yogyakarta.

Suharti, L \& Sirine, H. 2011. "Faktor-faktor yang Berpengaruh terhadap Niat Kewirausahaan (Studi terhadap Mahasiswa Universitas Kristen Satya Wacana Salatiga)". Jurnal Manajemen dan Kewirausahaan, 2. September 2012.

Sukidjo. 2011. Membudayakan Kewirausahaan. WUNY Majalah IImiah Populer Tahun XII, Nomor 1, Januari 2011. Yogyakarta: Universitas Negeri Yogyakarta.

Wijaya, Tony. 2007. Hubungan adversity intelligence dengan intensi berwirausaha. Jurnal Manajemen dan Kewirausahaan 9(2): 117-127.

Wijaya, Tony. 2008. Kajian Model Empiris Perilaku Berwirausaha UKM DIY dan Jawa Tengah. Jurnal Manajemen dan Kewirausahaan 10(2): 93-104. 